\section{Evaluation of Rootstocks on Harvest Metrics of 'Pinot Noir clone 02A' Wine Grapes in Maritime Western Washington}

\author{
Michelle M. Moyer ${ }^{1,4}$, Jaqueline King ${ }^{2}$, and Gary Moulton ${ }^{3}$
}

ADDITIONAL INDEX WORDs. maritime wine grapes, wine grape rootstocks, Vitis vinifera

Summary. The Puget Sound American Viticulture Area (AVA), located west of the Cascade Mountain Range in Washington State, is a large and uniquely situated area with diverse topography and mesoclimates. Given the young age of the AVA, little formal information exists on the appropriate rootstock-scion combination in wine grapes ( Vitis vinifera) for the region. This project reports on a series of rootstock trials from 2003 to 2007, which evaluated the influence of '420A Millardet et de Grasset', '3309 Couderc', '101-14 Millardet et de Grasset' (all Vitis hybrids), and a self-rooted control on basic harvest metrics of the wine grape scion 'Pinot noir clone 02A'. At the warmer site in Everson, WA, rootstocks had no effect on final juice harvest metrics measured by soluble solids, titratable acidity (TA), and $\mathrm{pH}$. At the cooler site in Mount Vernon, WA, the use of rootstocks did not always influence soluble solids or $\mathrm{pH}$ but did reduce final harvest TA, a desired effect for the region that is typified by low sugar-high TA wines. Even with a reduction in TA in some rootstock-scion combinations, overall, TA remained at the upper end or above the range typically desired for many wine styles.

$\mathrm{P}$ acific northwestern North America is the largest wine grape production region outside of California, with over 86,000 acres spread across Washington, Oregon, and British Columbia [Bremmer and Bremmer, 2014; U.S. Department of Agriculture (USDA), 2012, 2017]. There are 55,445 acres of wine grapes in Washington, of which 99.8\% lay east of the Cascade Mountains (USDA, 2017). However, there is a growing industry in the Puget Sound AVA, which is climatologically similar to most of the Oregon wine grape production areas. This AVA is one of the largest in total available area, encompassing over 4.75 million acres, but contains only 102 acres of wine grapes (USDA, 2017). From a wine marketing standpoint, it is one of the best-situated AVAs, given that it includes or neighbors the

\footnotetext{
Support for this project was provided by the Washington State Grape and Wine Research Program and the Northwest Center for Small Fruit Research.

${ }^{1}$ Department of Horticulture, Washington State University-Irrigated Agriculture Research and Extension Center, Prosser, WA 99350

${ }^{2}$ Department of Horticulture, Washington State University-Northwest Research and Extension Center, Mount Vernon, WA 98273

${ }^{3}$ Formerly Department of Horticulture, Washington State University-Northwest Research and Extension Center, Mount Vernon, WA 98273

${ }^{4}$ Corresponding author. E-mail: michelle.moyer@ wsu.edu.

https://doi.org/10.21273/HORTTECH04170-18
}

major metropolitan areas of Portland, OR; Seattle, WA; and Vancouver, BC, Canada.

The Puget Sound AVA is characterized by its diversity in climates and is the only Washington AVA located west of the Cascade Mountains. To highlight this diversity, weather (Washington State University, 2018) from extreme areas in this AVA in 2012 are described below. The year 2012 was chosen, as the grape and wine industry across the state of Washington tends to characterize that year as "average" in terms of temperature and precipitation. Rainfall in the region ranged from 14.4 to 60.13 inches ("Sequim" and "Tumwater SW" stations, respectively). The rainfall pattern is dominated by winter precipitation; low summer precipitation in some years typically results in the need for supplemental irrigation. Modified by the Pacific Ocean, the frost-free period in the AVA averages at $188 \mathrm{~d}$ but ranges from 143 to $245 \mathrm{~d}$ (same weather stations as aforementioned), making frost risk for most of the AVA a nonmajor threat.

The average heat accumulation in the area ranged from less than 1100 to just greater than 2000 growing degree days (GDD), base $50{ }^{\circ} \mathrm{F}$ ("Sequim" and "Seattle" stations, respectively); however, 2000 GDD is generally considered the minimum heat units necessary to ripen traditional wine grape varieties (Amerine and Winkler, 1944; Moyer et al., 2014). Thus, heat accumulation in the growing region is a potential production limitation in this AVA. To help mitigate the challenges posed by a cooler growing season, research on short-season/cool-tolerant varieties began in the 1970s at Washington State University's Northwest Research and Extension Center in Mount Vernon, WA. These wine grape trials provided essential information to commercial wine grape producers on the best varieties for production in this climate. As a result of this research, white-fruited varieties such as Siegerrebe, Madeleine Angevine, and Muller-Thurgau (all $V$. vinifera) have already proven successful in commercial production.

A renewed interest in variety trials occurred in the early 2000 s, with the focus on addressing the potential threat of phylloxera (Daktulosphaira vitifoliae), the shift in wine consumer preference to red wine (Olsen et al., 2006), and the related increase in price premiums associated with red varietals. Specifically, there was an interest in the Puget Sound AVA to produce 'Pinot Noir' after seeing the success of the variety in Willamette Valley, OR. However, the cool growing season of the Puget Sound AVA posed challenges in adequately and consistently ripening 'Pinot Noir' and controlling vine canopy development which resulted in very large vines with overshaded fruit. The lack of control

\begin{tabular}{llll}
\hline $\begin{array}{l}\text { Units } \\
\text { To convert U.S. to SI, } \\
\text { multiply by }\end{array}$ & U.S. unit & SI unit & $\begin{array}{l}\text { To convert SI to U.S., } \\
\text { multiply by }\end{array}$ \\
\hline 1 & $\%$ & $\mathrm{~g} / 100 \mathrm{~mL}$ & $\mathrm{l}$ \\
0.4047 & $\mathrm{acre}(\mathrm{s})$ & $\mathrm{ha}$ & 2.4711 \\
29.5735 & $\mathrm{fl} \mathrm{oz}$ & $\mathrm{mL}$ & 0.0338 \\
0.3048 & $\mathrm{ft}$ & $\mathrm{m}$ & 3.2808 \\
2.54 & inch $(\mathrm{es})$ & $\mathrm{cm}$ & 0.3937 \\
0.4536 & $\mathrm{lb}$ & $\mathrm{kg}$ & 2.2046 \\
1.6093 & $\mathrm{mile}(\mathrm{s})$ & $\mathrm{km}$ & 0.6214 \\
$\left({ }^{\circ} \mathrm{F}-32\right) \div 1.8$ & ${ }^{\circ} \mathrm{F}$ & ${ }^{\circ} \mathrm{C}$ & $\left({ }^{\circ} \mathrm{C} \times 1.8\right)+32$
\end{tabular}


over the timing of water application due to rainfall patterns in the area limited the greatest tool in canopy management: deficit irrigation (Wample and Smithyman, 2002). However, the use of rootstocks may help overcome these challenges associated with pest resistance, timing of ripening, and canopy management, thus expanding the range of areas where high quality red wine such as 'Pinot Noir' can be produced. The trial described herein aimed to look at the influence of rootstocks on the harvest parameters of 'Pinot Noir 02A'. Rootstocks used in this study were selected for pest resistance, for their potential to advance fruit maturity or influence fruit composition, and/or control vine vigor (Bettiga et al., 2003; Catlin, 1991; Reynolds and Wardle, 2001; Ruhl et al., 1988; Shaffer et al., 2004), but only the effects on fruit maturity are discussed in this report.

\section{Materials and methods}

Weather data. Temperature data were collected using local temperature loggers (RH-52; Avatel Technologies, Brandon, FL) at each of the vineyard sites (site-specific information reported below). Growing degree day unit accumulation was calculated from 1 Apr. to 31 Oct. for each year, using $50{ }^{\circ} \mathrm{F}$ as a base temperature. To calculate GDD units per day, the base temperature was subtracted from the average daily temperature. In the event that this calculation resulted in a negative number, the calculated negative number was reset to zero. Figure 1 also displays the monthly average minimum and maximum temperatures, and total precipitation that were recorded at AgWeatherNet stations nearest the research sites. These stations included "WSU Mount Vernon," which was less 0.6 miles from the Mount Vernon research site, and "Nooksack," which was within 6 miles of the Everson site and was the only AgWeatherNet station that was installed in that area at the time of the study.

ROOTSTOCK EVALUATION TRIALS. To consistently evaluate the influence of rootstock on scion development, the same variety clone of Pinot Noir was used across both locations and all rootstocks. 'Pinot Noir 02A' (Wadenswil clone Bl 10/16), a Swiss-origin clone, was selected for

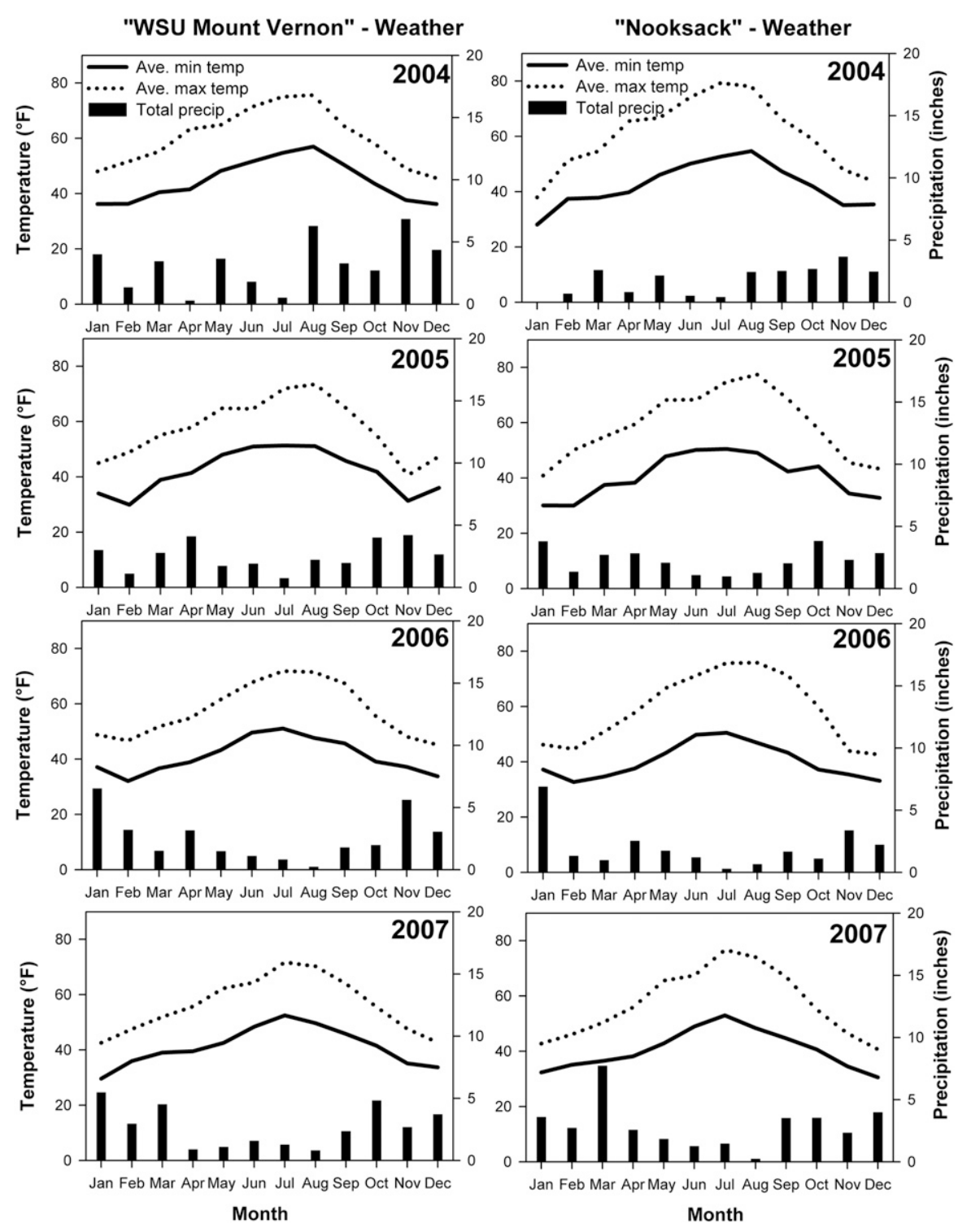

Fig. 1. Monthly average minimum temperature, maximum temperate, and total precipitation from AgWeatherNet Stations (Washington State University, 2018) nearest the research sites of Mount Vernon, WA [WSU Mount Vernon (left column)], and Everson, WA [Nooksack (right column)] for the years of 2004-07; $\left({ }^{\circ} \mathrm{F}-32\right) \div 1.8={ }^{\circ} \mathrm{C}, 1$ inch $=2.54 \mathrm{~cm}$.

its general early-ripening behavior and widespread planting in similar climate areas (i.e., western Oregon).

The primary goal was to determine if rootstocks could advance vine phenology (specifically, ripening) to combat limitations of a cooler growing season. The following rootstocks were used for evaluation; secondary considerations for rootstock selections are also listed: 1) '420A Millardet et de Grasset' [420A (Vitis berlandieri $\times$ Vitis rupestris selected for phylloxera resistance, low vigor, adaption to fertile soils, and ease of propagation)], 2) '3309 Couderc'
[3309C (Vitis riparia $\times V$. rupestris selected for phylloxera resistance, low to moderate vigor, adaption to deep soils, and ease of propagation)], and 3) '101-14 Millardet et de Grasset' [101-14 Mtg (V. riparia $\times V$. rupestris selected for phylloxera resistance, moderate vigor, adaption to deep soils, and ease of propagation)]. Selfrooted vines were used as control. Before the selection of these three rootstocks, an additional minitrial of rootstocks which also included 'Riparia Gloire' ( $V$. riparia), '44-53 Malègue' $[V$. riparia $\times$ (Vitis cordifolia $\times V$. rupestris)], 'Teleki 5C' (V. berlandieri $\times$ 
$V$. riparia), and 'Kober 5BB' ( $V$. berlandieri $\times V$. riparia) was conducted. However, because of lack of performance, these rootstocks were removed from evaluation. Initial observations indicated these discarded rootstocks performed better than selfrooted vines, but inferior to the three aforementioned varieties (data not shown). Washington State has strict plant quarantines, and as such, established populations of phylloxera have not been reported within the state, although populations have been reported in Willamette Valley, OR; this allows for the planting of self-rooted vines within the state boundaries.

Rootstock evaluation trials occurred in two locations; Everson, WA, and Mount Vernon, WA (Washington State University - Northwest Research and Extension Center). The soil at the site in Everson is a coarse-silty, mixed, superactive, mesic Fluventic Haploxerolls (pedon: Nooksack silt loam). The soil at the Mount Vernon site is a fine-silty, mixed, superactive, nonacid, mesic Fluvaquentic Endoaquepts (pedon: Puget silty clay loam) (USDA, 2018). The Everson site is located near lat. $48.92^{\circ} \mathrm{N}$, long. $122.34^{\circ} \mathrm{W}$ (specific coordinates omitted to protect private property owner). The Mount Vernon site is located at lat. $48.4391^{\circ} \mathrm{N}$, long. $122.3875^{\circ} \mathrm{W}$. Both vineyards were established in 2000 , with vine by row spacing at $5 \times 9 \mathrm{ft}$ in Everson and $6 \times 10 \mathrm{ft}$ in Mount Vernon. Vines were planted as dormant, rooted cuttings. The variety-rootstock combinations of Pinot Noir 02A self-rooted, Pinot Noir 02A grafted to 420A, and Pinot Noir 02A grafted to 101-14 Mtg were sourced from Duarte Nursery in Hughson, CA. The variety-rootstock combination of Pinot Noir 02A grafted to 3309C was sourced from Sonoma Grapevines, Inc. in Fulton, CA. Vines in both locations were trained to a double guyot, with a vertical shoot-positioned trellis system with a fruiting wire at 30 inches above the ground, a set of double wires (termed "catchwires") 12 inches above the fruiting wire, and single wires at 20 and 28 inches above the fruiting wire. After fruit set, clusters were thinned to one cluster per shoot, and fruitzone leaf removal around the clusters was completed. Canopy hedging to just above the top catchwire was completed in late July and again in late August to facilitate the installation of bird netting. Experimental design in both locations was a randomized block design. Each treatment included five adjacent vines per treatment replication, replicated across three vineyard rows (i.e., one treatment replication per row).

Trials were evaluated in 2004 and 2005 in Everson and from 2004 through 2007 in Mount Vernon. Juice soluble solids, $\mathrm{pH}$, and TA were evaluated in all years. Yield per vine was collected in 2006 and 2007. Dormant pruning weights, a reflection of vine vigor, were not collected during this study because of the repeated summer hedging of the canopy that was done at both sites in all years of the study. This repeated practice removed enough biomass to result in no vigor differences between treatments (data not shown). To evaluate sugar content, 10 berries per vine from five vines per treatment replication were arbitrary sampled (50 berries total per treatment replication). Berries were sampled from the shoulders, middle, and tip of clusters. Berries were crushed in a plastic bag and collected juice soluble solids were measured with a handheld temperature-compensating refractometer (ATC-1; Atago USA, Livermore, CA). The same juice was used to evaluate $\mathrm{pH}$ and TA (Phi 32; Beckman-Coulter, Indianapolis, IN). Titratable acidity was measured by titrating $0.1 \mathrm{~N}$ sodium hydroxide $(\mathrm{NaOH})$ solution into $5 \mathrm{~mL}$ of juice diluted with $25 \mathrm{~mL}$ of distilled deionized $\mathrm{H}_{2} \mathrm{O}$ until a $\mathrm{pH}$ of 8.2 was reached. Amount of $\mathrm{NaOH}$ was recorded, and percent TA was calculated as follows: TA (percent) $=$ $0.15 \times \mathrm{mL} 0.1 \mathrm{~N} \mathrm{NaOH}$ used.

Table 1. Annual growing degree day accumulation from on-site temperature recordings at both the Mount Vernon, WA, and Everson, WA, vineyard locations from 2004 to 2007.

\begin{tabular}{lcc}
\hline & \multicolumn{2}{c}{ Growing degree day accumulation $^{z}$} \\
\cline { 2 - 3 } Yr & Mount Vernon & Everson $^{2003}$ \\
2004 & 1,965 & 2,147 \\
2005 & 1,817 & 2,075 \\
2006 & 1,727 & 1,897 \\
2007 & 1,600 & 1,948 \\
2008 & 1,499 & 1,684 \\
6-year average & 1,523 & 1,587 \\
\hline
\end{tabular}

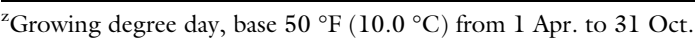

Statistical analyses. All data were analyzed using JMP statistical software (version 9; SAS Institute, Cary, NC). Data were analyzed using linear mixed models with replication as a random effect. Tukey's honest significant difference test was used for mean separation, with significance at $\alpha=0.05$.

\section{Results and discussion}

WeAther. The recorded GDD accumulation for both Mount Vernon and Everson is presented in Table 1. Additional years of temperature data beyond the years of this study are presented as additional trials at these two sites were conducted from 2008 until 2010 , allowing for continued temperature monitoring. Average monthly high and low temperatures, and total monthly precipitation as recorded by nearby AgWeatherNet stations (Washington State University, 2018), are presented in Fig. 1. The combined vintage and location variation allowed for a fair representation of rootstock performance across a broad range of sites that are available in the Puget Sound AVA.

RoOTSTOCK EVALUATION TRIALS. Only in 1 year of the study, 2004 (Tables 2 and 3), and in one location (Mount Vernon, WA), did the use of rootstocks significantly increase final soluble solids in harvested fruit. Rootstock 420A had significantly higher soluble solids than the selfrooted control $(20.13 \%$ compared with $18.00 \%$ soluble solids, respectively). This occurred in a vintage that was noted by above-average temperatures. Mount Vernon, WA, was 126 GDD units above average, whereas Everson, WA, was 185 GDD units above average. Noted by dryer summer months and where most vineyards 
do not have supplemental irrigation, this instance of increased soluble solids may not be related to advancement of maturity, but rather dehydration of the fruit. In all other years of the study, which were only slightly above average GDD accumulation to below average GDD accumulation, rootstock did not influence final soluble solids accumulation in the fruit (Tables 3 and 4). For context, acceptable ranges in soluble solids content can differ based on the desired wine style. In general, the recommendation soluble solids range for sparkling wine is $17 \%$ to $20 \%$, for white table wine is $19 \%$ to $23 \%$, and for red table wine is $20 \%$ to $24 \%$ (Boulton et al., 1996), indicating that chaptalization would be necessary at these sites for production of any wine style other than sparkling.

Final juice $\mathrm{pH}$ was not influenced by rootstock in either location during any year of the study (Tables 2-4).
The typical juice $\mathrm{pH}$ range acceptable for white wine production (without requiring substantial amelioration) is 3.1-3.4, with red wine musts falling in a slightly higher $\mathrm{pH}$ range $(3.3-$ 3.6) (Jackson, 2008). When the $\mathrm{pH}$ is below that, the must becomes an unsuitable environment for Saccharomyces cerevisiae yeast, thus slowing or stopping fermentation (Ough, 1966). When the $\mathrm{pH}$ is above that, the juice environment becomes favorable for

Table 2. Comparison of juice quality differences of the wine grape variety Pinot Noir 02A on different rootstocks in 2004. The trial was conducted at two different locations in western Washington state: Mount Vernon and Everson.

\begin{tabular}{|c|c|c|c|c|c|c|}
\hline \multirow[b]{2}{*}{ Location } & \multirow{2}{*}{$\begin{array}{c}\text { Date of } \\
\text { sampling }\end{array}$} & \multirow[b]{2}{*}{ Juice evaluation $^{\mathrm{z}}$} & \multicolumn{4}{|c|}{ Rootstock $^{\mathrm{y}}$} \\
\hline & & & 3309C & 101-14 Mtg & $420 \mathrm{~A}$ & Self \\
\hline \multirow{6}{*}{$\begin{array}{l}\text { Mount Vernon } \\
\qquad \text { GDD }=1,817^{x}\end{array}$} & \multirow[t]{2}{*}{24 Sept. } & Soluble solids (\%) & 16.97 & 19.36 & 17.40 & 15.30 \\
\hline & & Titratable acidity $(\mathrm{g} / 100 \mathrm{~mL})$ & $0.79 b^{w}$ & $0.85 \mathrm{~b}$ & $0.86 \mathrm{~b}$ & $1.32 \mathrm{a}$ \\
\hline & \multirow[t]{2}{*}{30 Sept. } & Soluble solids $(\%)$ & $18.00 \mathrm{ab}$ & $18.50 \mathrm{a}$ & $18.40 \mathrm{a}$ & $16.47 \mathrm{~b}$ \\
\hline & & $\mathrm{pH}$ & 3.11 & 3.11 & 3.09 & 3.00 \\
\hline & \multirow{2}{*}{14 Oct. } & $\mathrm{pH}$ & 3.11 & 3.10 & 3.14 & 3.00 \\
\hline & & Titratable acidity $(\mathrm{g} / 100 \mathrm{~mL})$ & $0.91 \mathrm{a}$ & $0.94 \mathrm{a}$ & $0.92 \mathrm{a}$ & $1.26 \mathrm{~b}$ \\
\hline \multirow[t]{5}{*}{ Everson GDD $=2,075$} & \multirow[t]{3}{*}{27 Sept. } & Soluble solids $(\%)$ & 20.07 & 20.40 & 19.73 & 19.53 \\
\hline & & $\mathrm{pH}$ & 2.93 & 2.88 & 2.93 & 2.90 \\
\hline & & Titratable acidity $(\mathrm{g} / 100 \mathrm{~mL})$ & 0.94 & 0.83 & 0.86 & 1.03 \\
\hline & \multirow{2}{*}{5 Oct. } & $\mathrm{pH}$ & $\mathrm{n} / \mathrm{a}$ & 2.77 & 2.84 & 2.84 \\
\hline & & Titratable acidity $(\mathrm{g} / 100 \mathrm{~mL})$ & $\mathrm{n} / \mathrm{a}$ & 0.74 & 0.81 & 0.75 \\
\hline
\end{tabular}

${ }^{\mathrm{z}} 1 \mathrm{~g} / 100 \mathrm{~mL}=1 \%$.

y3309 = '3309 Couderc', 101-14 Mtg = '101-14 Millardet et de Grasset', 420A = '420A Millardet et de Grasset', Self = self-rooted control .

${ }^{\mathrm{x}}$ Growing degree days base $50{ }^{\circ} \mathrm{F}\left(10.0^{\circ} \mathrm{C}\right)$ from 1 Apr. to 31 Oct.

wValues with different letters within a row indicate significant difference at $\alpha=0.05$ (Tukey's honestly significant difference).

GDD = Growing degree days.

Table 3. Comparison of juice quality differences of the wine grape variety Pinot Noir 02A on different rootstocks in 2005. The trial was conducted at two different locations in western Washington state: Mount Vernon and Everson.

\begin{tabular}{|c|c|c|c|c|c|c|}
\hline \multirow[b]{2}{*}{ Location } & \multirow{2}{*}{$\begin{array}{c}\text { Date of } \\
\text { sampling }\end{array}$} & \multirow[b]{2}{*}{ Juice evaluation $^{z}$} & \multicolumn{4}{|c|}{ Rootstock $^{\mathrm{y}}$} \\
\hline & & & 3309C & 101-14 Mtg & $420 \mathrm{~A}$ & Self \\
\hline \multirow{6}{*}{$\begin{array}{l}\text { Mount Vernon } \\
\qquad \text { GDD }=1,727^{x}\end{array}$} & 29 Sept. & Soluble solids (\%) & 18.53 & 18.53 & 19.43 & 17.33 \\
\hline & & Titratable acidity $(\mathrm{g} / 100 \mathrm{~mL})$ & $1.00 \mathrm{~b}$ & $0.96 \mathrm{~b}$ & $0.88 \mathrm{~b}$ & $1.32 \mathrm{a}$ \\
\hline & 5 Oct. & Soluble solids $(\%)$ & 19.77 & 19.67 & 20.37 & 18.53 \\
\hline & & $\mathrm{pH}$ & $3.15 \mathrm{a}$ & $3.14 \mathrm{a}$ & $3.17 \mathrm{a}$ & $3.02 \mathrm{~b}$ \\
\hline & & $\mathrm{pH}$ & 3.56 & 3.59 & 3.61 & 3.45 \\
\hline & & Titratable acidity $(\mathrm{g} / 100 \mathrm{~mL})$ & $1.05 \mathrm{~b}$ & $1.05 \mathrm{~b}$ & $0.97 \mathrm{~b}$ & $1.42 \mathrm{a}$ \\
\hline \multirow[t]{3}{*}{ Everson GDD = 1,867 } & 11 Oct. & Soluble solids $(\%)$ & 19.90 & 19.47 & 19.93 & 19.73 \\
\hline & & $\mathrm{pH}$ & 3.09 & 3.16 & 3.13 & 3.04 \\
\hline & & Titratable acidity $(\mathrm{g} / 100 \mathrm{~mL})$ & 1.00 & 0.87 & 0.91 & 1.00 \\
\hline
\end{tabular}

${ }^{\mathrm{z}} 1 \mathrm{~g} / 100 \mathrm{~mL}=1 \%$.

y3309 = '3309 Couderc', 101-14 Mtg = '101-14 Millardet et de Grasset', 420A = ‘420A Millardet et de Grasset', Self = self-rooted control.

${ }^{\mathrm{x}}$ Growing degree days base $50^{\circ} \mathrm{F}\left(10.0^{\circ} \mathrm{C}\right)$ from 1 Apr. to 31 Oct.

walues with different letters within a row indicate significant difference at $\alpha=0.05$ (Tukey's honestly significant difference).

GDD = Growing degree days. 
spoilage microorganisms. In the two warmer years for Mount Vernon, 2004 and 2005 , juice $\mathrm{pH}$ for all treatments was within an appropriate range (Tables 2 and 3). However, in cooler vintages, such as 2006 and 2007, juice $\mathrm{pH}$ was below the minimum threshold, and $\mathrm{pH}$ adjustments in a commercial production scenario would be necessary to create an environment appropriate for $S$. cerevisiae fermentation. These results indicate that the use of these three rootstocks in western Washington is an inappropriate cultural approach in an effort for adjusting pre-fermentation must $\mathrm{pH}$.

The use of rootstocks consistently had a beneficial effect on final juice TA (Tables 2-4), except in 2006 in Mount Vernon. In those years where significant differences were observed, the self-rooted control had higher TA than all the rootstock selections. In 2006, whereas no significant differences were observed between the different rootstocks and the self-rooted control, the self-rooted control had the highest overall average TA. In this 2006 vintage, all treatments had TA levels that would be considered unacceptable and in need of adjustment. Typical juice TA ranges that are acceptable for wine production (without requiring substantial amelioration) are between 0.55 and $0.85 \mathrm{~g} / 100 \mathrm{~mL}$ (Jackson,
2008). Although the use of rootstocks decreased TA relative to the self-rooted control, in cooler vintages TA was still higher than desirable, indicating that acid adjustment may be necessary regardless of the use of rootstock.

In 2006, yield was significantly influenced by the use of rootstocks (Table 5). Self-rooted vines had significantly higher yield than any of the grafted combinations. These differences were not observed in 2007 , and weather conditions were not exceptionally favorable for fruit development in that year (i.e., in-season heat accumulation was at 1499 GDD). Past studies in Oregon indicate more explicit differences in yield, with 3309C consistently resulting in overcropped vines (Shaffer et al., 2004), but this was not seen in our study. Although this limited study provides some evidence for yield management (Table 5 ), a direct comparison of the rootstocks cannot be made given that the vines were actively crop-thinned to one cluster per shoot in all rootstocks and in both years where total vine yield was collected.

\section{Conclusion}

Throughout this trial, the use of rootstocks did not influence final harvest parameters in Everson, WA, but did so in some years in Mount Vernon, WA. Over the course of the study, Everson was warmer on average (Table 1; Fig. 1) than Mount Vernon. Both sites would be on the very low end of Region I of the Winkler Viticulture Region scale (Amerine and Winkler, 1944). Whereas originally designed to categorize Californian product regions and determine varietal appropriateness based on GDD accumulation between bloom and harvest and GDD accumulation the month proceeding harvest, its use has been misapplied to categorize site appropriateness over what is considered the entire growing season for most northern climates (i.e., GDD accumulation period between 1 Apr. and 31 Oct., rather than phenological stages). Subsequent research has refined this scale, particularly on the cooler end, to demonstrate the appropriateness of early-ripening wine grape varieties and some hybrids at temperature accumulations between 1500 and 1800 GDD (Jones et al., 2010). However, that work admittedly included a lower threshold baseline from evidence of new commercial plantings in cool sites (i.e., the Puget Sound AVA), rather than on long-term performance of those varieties inclusive of annual variability in ripening. Since that publication, though, there has

Table 4. Comparison of juice quality differences of the wine grape variety Pinot Noir 02A on different rootstocks in 2006 and 2007. The trial was conducted in western Washington state at Mount Vernon.

\begin{tabular}{|c|c|c|c|c|c|c|}
\hline \multirow[b]{2}{*}{ Location } & \multirow{2}{*}{$\begin{array}{c}\text { Date of } \\
\text { sampling }\end{array}$} & \multirow[b]{2}{*}{ Juice evaluation $^{\mathrm{z}}$} & \multicolumn{4}{|c|}{ Rootstock $^{\mathrm{y}}$} \\
\hline & & & 3309 & 101-14 Mtg & $420 \mathrm{~A}$ & Self \\
\hline \multirow[t]{2}{*}{$2006 \mathrm{GDD}=1,600^{\mathrm{x}}$} & 23 Oct. & Soluble solids (\%) & 19.15 & 19.20 & 19.30 & 18.30 \\
\hline & & Titratable acidity $(\mathrm{g} / 100 \mathrm{~mL})$ & 1.20 & 1.17 & 1.35 & 1.67 \\
\hline \multirow[t]{2}{*}{2007 GDD = 1,499 } & 26 Oct. & Soluble solids $(\%)$ & 18.80 & 19.07 & 18.60 & 18.13 \\
\hline & & $\mathrm{pH}$ & 3.02 & 3.02 & 3.02 & 2.94 \\
\hline
\end{tabular}

${ }^{\mathrm{z}} 1 \mathrm{~g} / 100 \mathrm{~mL}=1 \%$

y3309 = '3309 Couderc', 101-14 Mtg = '101-14 Millardet et de Grasset', 420A = '420A Millardet et de Grasset', Self = self-rooted control

${ }^{\mathrm{x}}$ Growing degree days base $50^{\circ} \mathrm{F}\left(10.0^{\circ} \mathrm{C}\right)$ from 1 Apr. to 31 Oct.

wValues with different letters within a row indicate significant difference at $\alpha=0.05$ (Tukey's honestly significant difference)

GDD = Growing degree days.

Table 5. Effects of different rootstocks on yield of the wine grape variety Pinot Noir 02A in 2006 and 2007 in western Washington state at the Mount Vernon site.

\begin{tabular}{|c|c|c|c|c|c|c|}
\hline \multirow[b]{2}{*}{ Yr } & \multirow[b]{2}{*}{ Date of sampling } & \multirow[b]{2}{*}{ Yield $^{\mathrm{y}}$} & \multicolumn{4}{|c|}{ Rootstock $^{y}$} \\
\hline & & & 3309C & 101-14 Mtg & $420 \mathrm{~A}$ & Self \\
\hline 2006 & 25 Oct. & $\mathrm{lb} /$ vine & $5.28 b^{x}$ & $6.26 \mathrm{~b}$ & $5.10 \mathrm{~b}$ & $9.97 \mathrm{a}$ \\
\hline
\end{tabular}

${ }^{\mathrm{z}} 1 \mathrm{lb}=0.4536 \mathrm{~kg}$

y3309 = '3309 Couderc', 101-14 Mtg = '101-14 Millardet et de Grasset', 420A = '420A Millardet et de Grasset', Self = self-rooted control

${ }^{\mathrm{x}}$ Values with different letters within a row indicate significant difference at $\alpha=0.05$ (Tukey's honestly significant difference). 
been an increase in successful commercial production of early-ripening winegrape varieties in the region, as growers have selected sites that maximize the available GDD for their area (Moyer et al., 2014; USDA, 2017).

There are many tools viticulturists can use, however, to overcome site limits, inclusive of the adoption of different training systems, site modifications, water management through controlled irrigation, careful attention to health status of the vine (e.g., nutrient management and disease), the appropriate selection of climate-suitable varieties and clones, and, in this case, rootstocks. In this study, the use of rootstocks did improve fruit harvest metrics relative to an own-rooted control in a few years; but overall, harvest metrics were still lower than what is generally considered appropriate for table wine production. Although the advancement of ripening, in this case measured as a combination of soluble solids, TA, and $\mathrm{pH}$, was not consistently altered using rootstocks, the general reduction of TA through the adoption of rootstocks might prove helpful for western Washington grape producers in combination with juice adjustments in the winery.

\section{Literature cited}

Amerine, M.A. and A.T. Winkler. 1944. Composition and quality of musts and wines of California grapes. Hilgardia 15:493-673.

Bettiga, L., D.A. Golino, G. McGourty, R.J. Smith, P. Verdegaal, and E. Weber.
2003. Rootstock selection, p. 12-15. In: L.P. Christensen, N.K. Dokoozlian, M.A. Walker, and J.A. Wolpert (eds.). Wine grape varieties in California. Univ. California Agr. Natural Resources Publ. 3419.

Boulton, R.B., V.L. Singleton, L.F. Bisson, and R.E. Kunkee. 1996. Principles and practices of winemaking. Chapman and Hall, New York, NY.

Bremmer, L. and J. Bremmer. 2014. British Columbia winegrape acreage report. 8 Nov. 2017. <http://www.bcwgc.org/ resource/acreage-report>.

Catlin, T. 1991. Alternative rootstock update. Amer. Soc. Enol. Viticult. Tech. Projects Committee and Univ. California Coop. Ext., Oakland, CA.

Jackson, R.S. 2008. Wine science: Principles and applications. 3rd ed. Elsevier, New York, NY.

Jones, G.V., A.A. Duff, A. Hall, and J.W. Myers. 2010. Spatial analysis of climate in winegrape growing regions in the western United States. Amer. J. Enol. Viticult. 61:313-326.

Moyer, M.M., G. Moulton, and T. Henick-Kling. 2014. Growing winegrapes in maritime western Washington. Washington State Univ. Ext. Publ. EM068e.

Olsen, J.E., E.C. Thach, and L. Nowak. 2006. Consumer socialization of U.S. wine consumers. 25 Sept. 2018. <http:// academyofwinebusiness.com/wp-content/ uploads $/ 2010 / 05 /$ olsen.pdf $>$.

Ough, C.S. 1966. Fermentation rates of grape juice. II Effect of initial brix, $\mathrm{pH}$, and fermentation temperature. Amer. J. Enol. Viticult. 17:20-26.

Reynolds, A.G. and D.A. Wardle. 2001. Rootstocks impact vine performance and fruit composition of grapes in British Columbia. HortTechnology 11:419427.

Ruhl, E.H., P.R. Clingeleffer, P.R. Nicholas, R.M. Cirami, M.G. McCarthy, and J.R. Whiting. 1988. Effect of rootstocks on berry weight and $\mathrm{pH}$, mineral content, and organic acid concentrations of grape juice of some wine varieties. Austral. J. Expt. Agr. 28:119-125.

Shaffer, R., T.L. Sampaio, J. Pinkerton, and M.C. Vasconcelos. 2004. Grapevine rootstocks for Oregon vineyards. Oregon State Univ. Ext. EM 8882.

U.S. Department of Agriculture. 2012. Oregon vineyard report-2011. 8 Nov. 2017. <https://www.nass.usda.gov/ Statistics_by_State/Oregon/Publications/ Vineyard_and_Winery/v_2011_final.pdf>.

U.S. Department of Agriculture. 2017. Washington vineyard acreage report2017. 8 Nov. 2017. <https://www.nass. usda.gov/Statistics_by_State/Washington/ Publications/Fruit/2017/Vineyard2017>.

U.S. Department of Agriculture. 2018. Official soil series description. 20 Sept. 2018. <https://soilseries.sc.egov.usda.gov/ osdname.aspx $>$.

Wample, R. and R. Smithyman. 2002. Regulated deficit irrigation as a water management strategy in Vitis vinifera production. 24 Sept. 2018. <http:// www.fao.org/docrep/004/Y3655E/ Y3655E00.htm>.

Washington State University. 2018. AgWeatherNet, the Washington Agricultural Weather Network. 25 Sept. 2018. $<$ https://weather.wsu.edu>. 